\title{
Projects ANd Conference Reports
}

Project Meltho-Syriac Fonts for the Microsoft Windows 2000 TM Operating System

\section{George A. Kiraz, Bell Laboratories, USA}

[1] Since 1997, the Syriac Computing Institute (SyrCOM) [now Beth Mardutho: The Syriac Institute] has been working on the design and implementation of Syriac software on the Microsoft Windows $^{\mathrm{TM}}$ platform. The project will deliver software that works on any computer with Windows $2000^{\mathrm{TM}}$ operating system, allowing users to write Syriac texts in various fonts and scripts (Estrangelo, Serto or West Syriac, and East Syriac).

The first step of the project was to have Syriac added to Unicode, the newly international coding scheme, which is a prerequisite to have Syriac work under Windows. SyrCOM participated in putting forward a proposal to the Unicode Technical Committee (see http://www.unicode.org/pending/syriac). The proposal was accepted by the Unicode Consortium and the International Standard Organization. In fact, through the laborious work of Paul Nelson at Microsoft, there is already now built-in support for Syriac in the forthcoming Windows $2000^{\mathrm{TM}}$ Operating System, with Syriac Unicode support.

Although Project Meltho was initially aimed at 'wordprocessing', it has matured now into a full Syriac support for the Windows $2000^{\mathrm{TM}}$ Operating System, allowing users to use Syriac in any Windows-based application that uses published Uniscribe APIs (the functions that handle complex scripts in Windows). This gives the end-user a wide range of applications to use Syriac with: wordprocessing, databases, Web pages, emails, presentations, etc. This also means that programmers who wish to program special applications for Syriac will not have to do any special handling for Syriac text; Windows handles it for them! Additionally, Syriac is in the list of languages that will be supported by the next version of Microsoft Office ${ }^{\mathrm{TM}}$ products (i.e., Word ${ }^{\mathrm{TM}}$, Access ${ }^{\mathrm{TM}}$, PowerPoint ${ }^{\mathrm{TM}}$, etc.). Already, the web browser Internet Explorer $^{\mathrm{TM}} 5$ supports Syriac using Unicode encoding. All this is possible provided the user has the appropriate (not any) Syriac fonts. 
Project Meltho aims at providing the appropriate Syriac fonts for the Syriac-users community free of charge. To achieve this, SyrCOM made use of Kiraz's fonts for the DOS-based MultiLingual Scholar ${ }^{\mathrm{TM}}$ software, and created from them new OpenType fonts. The OpenType font scheme is the latest font technology; it allows for automatic contextual replacement of letters (e.g., initial, medial, final), the accurate positioning of vowels and points per letter (e.g., high diacritic on Lomadh, but low on Yudh), the creation of ligatures, etc.

SyrCOM believes that the quality of its fonts must be outstanding and must be of the quality of other Latin fonts that users are accustomed to. Hence, SyrCOM plans to have the final 'touches' of its fonts completed by a professional typographer. This includes 'cleaning-up' the fonts, making sure that spacing is accurate, and providing Latin support in the Syriac fonts in order to use them in multi-lingual documents without having to change the font every time the user goes from Syriac to Latin. Additionally, the professional typographer will 'hint' the fonts, a process that makes the fonts readable at low-resolutions (e.g., screens for Web pages, and 9- or 8-pt printing).

A leading professional typographer, with an outstanding record in foreign-language font design (especially Arabic which presents the same challenges Syriac does), has agreed to work on the SyrCOM fonts. The cost to produce each font will be $\$ 1500$. In order to cover its expense, SyrCOM is calling academic and community institutions, and end-users to support this endeavor through its "Adopt a Syriac Font Program." Institutions and individuals may chose to adopt an entire font for $\$ 1500$, or parts of a font for $\$ 500$. In the latter case, SyrCOM will put together the contributions of three contributors to cover the cost of a font. The names of contributors will be acknowledged.

The fonts will be distributed by SyrCOM to users free of charge through its web site. The fonts will be copyrighted by SyrCOM, and no commercial use of them will be allowed by any party including SyrCOM. The fonts will cover Estrangelo, Serto (West Syriac), and East Syriac. In addition to supporting Classical Syriac, full support will be given for Turoyo, Swadaya (modern Assyrian), Garshuni, and Christian-Palestinian Aramaic. SyrCOM plans to have the fonts available to the public in the first quarter of 2000. 


\section{ACKNOWLEDGEMENTS}

[8] SyrCOM would like to thank the Center for the Preservation of Ancient Religious Texts, Utah, for a general grant. Acknowledgements are also due to Paul Nelson of Microsoft for adding the Syriac support in Windows $2000^{\mathrm{TM}}$ on his free time. The Unicode Proposal was made possible through the assiduous efforts of Paul Nelson, George Kiraz, and Sargon Hasso. Microsoft, represented by Michael Suignard and Murray Sargent, kindly acted as a sponsor for Syriac at the Unicode Technical Committee, and in the person of Andy Abbar, provided SyrCOM with software at the early stages of this project.

[9] For further information and contributions, please contact George A. Kiraz (Bell Labs [now Gorgias Press]). 
The Thirteenth International Conference on Patristic Studies. Oxford, 16-21 August 1999.

\section{SUSAN A. HARVEY, BROWN UNIVERSITY}

[1] The Thirteenth International Conference on Patristic Studies convened in Oxford, England during the week of 16-21 August 1999 with roughly 800 participants. Among the many papers, there were a feast of offerings for the Syriac scholar. In the Communications, twenty-three papers were delivered in the Syriac section over three days; other Syriac papers, notably one by Kathleen McVey, were presented in other Communication sections defined by broader themes. Four Master Theme papers were presented in the "Ephrem/Syria" session over the course of two days. These were given by Sebastian Brock, Phil Botha, Sidney Griffith and Ephrem Lash. In fact, this Master Theme session attracted such a large audience that the original room assignment had to be changed to accommodate the crowd! A further four papers containing substantial Syriac scholarship were delivered at other Master Theme sessions, again defined by broader themes. These were given by J.W. Drijvers, Alexander Golitzin, Simon Mimouni, and Pauline Allen. Finally, the Public Lecture by Susan Harvey drew heavily on Syriac sources as well as Greek. Syriacists were additionally happy to find a full day's Communication section given to Armenian and Georgian papers.

It was a great pleasure to find many graduate students among those offering and attending the Syriac papers, and further, to learn that these students had come from as wide a geographical expanse as the conference itself. One had every indication that Syriac studies is thriving in many universities around the world. The opportunity to meet together was, as always, a rare and wonderful treat-inspiring and energizing for all. 
Symposium on Michael the Syrian (1126-1199).

Ma’arat Saydnaya, Damascus, 1-8 October 1999.

\section{Adapted for Hugoye from a Communiqué by the St. Ephrem Theological Seminary, Damascus.}

[1] The $800^{\text {th }}$ anniversary of the passing away of the Syrian Orthodox Patriarch of Antioch and scholar Mor Michael the Syrian was celebrated at an international Symposium convened by H.H. Patriarch Mor Ignatius Zakka I Iwas, Patriarch of Antioch and all the East, and H.E. Metropolitan Mor Gregorios Yuhanna Ibrahim, Metropolitan of Aleppo.

The Symposium met at the Patriarchate's new educational facility, St. Ephrem Theological Seminary at Ma'arat Saydnaya outside Damascus on Oct 1-8, 1999. Twenty scholars from Belgium, England, Germany, Lebanon, Syria and the United States delivered papers on a wide variety of topics related to the great historical chronicle produced in the $12^{\text {th }}$ century by Mor Michael, at what was the first scholarly meeting in modern times devoted to the study of Syriac historiography. Each session concluded with rigorous and learned discussions. A concert of sacred music presented by the seminarians of St. Ephrem's preceded the symposium. Participants were also entertained with an excursion to local shrines and monasteries, and a magnificent dinner hosted by H.H. Mor Ignatius Zakka I. Speakers included: Prof. Michael Van Esbroeck, Prof. Susan Ashbrook Harvey, V. Rev. Dr. Joseph Tarzi, Ms. Dorothea Weltecke, Ms. Emma Loosley, Prof. Michael Morony, Dr. May Touma, H. E. Metropolitan Mor Gregorious Yuhanna Ibrahim, Rev. Fr. Abdo Badwi and Mr. Fadi Baroody, Rev. Fr. Elias Khalifeh, H.E. Archbishop Theophilos George Saliba, Prof. Dr. Robert Betts, and Prof. Dr. Seta Badoyan.

H.H. Mor Ignatius Zakka I Iwas gave the Inaugural Address of the Symposium, stressing the importance of the Syriac scholarship in establishing a true history not only of the Syrian Orthodox people, but also of the Middle East as a whole. "I do implore respectful scholars and orientalists," said H.H. "to attempt rewriting the history of this part of the world depending not only on western sources, but also on the historians from our Syrian Orthodox Church like St. Michael, and not only on the history recorded by the victorious, but also on the history written by the defeated people." 
